\title{
Strategic Leadership and Organizational Performance of Directorate of Criminal Investigations in Nairobi County, Kenya
}

\author{
Eswari Njoki Bose ${ }^{1}$, Dr. Priscillah Ndegwa ${ }^{2}$ \\ ${ }^{1}$ School of Business, Kenyatta University, Kenya \\ ${ }^{2}$ Department of Business Administration, Kenyatta University, Kenya
}

\begin{abstract}
Performance of an organization relies on the strategic moves and direction that it makes. For all strategies formulated to work, the leadership itself must be strategic. The security sector in Kenya has been faced with a myriad of challenges ranging from low public confidence, poor leadership, incompetence, poor housing and other facilities, limited funding and above all poor strategy formulation and implementation. Strategic leadership is the leader's ability to anticipate, envision, maintain flexibility, and empower others to create strategic change as necessary. This general objective of this study was to establish the influence of strategic leadership on the organizational performance of the Directorate of Criminal Investigations in Nairobi City County, Kenya. The specific objectives of this study were to establish the influence of management competencies on organizational performance of the DCI, to examine the effect of corporate culture on organizational performance of the DCI, to establish the influence of shareholder involvement on organizational performance of the DCI and to determine the effect of ethical practices on performance of the DCI. The study was anchored on trait leadership theory, path-goal leadership theory and the transformation leadership theory. The study used descriptive research design. The target population of this study comprised the senior officers from the 10 units in the DCI in Nairobi City County who total to 141. Stratified random sampling was used to select the sample size of 42 which is 30 percent of the total study population. The study used both primary and secondary data. Primary data was collected using a semi structured questionnaire to be administered to the officers through drop and pick later method. Secondary data was obtained from the DCI strategic plans, records, annual reports and human resource data base. Data collected was analysed through descriptive and inferential statistics by the use of SPSS. Findings were presented by use of tables, frequencies, percentages, means and standard deviation. The study found that given the significance of significance of the variance ( $p$-Value $<0.05)$ and $F$-Value is 44.283 and further supported by $R$-Square $=0.76$, it was concluded that management competencies, corporate culture, stakeholder involvement, and ethical practices are all essential strategic leadership aspect that require complete adoption if performance of an organization has to improve to the desired level. Of particular importance to achieve this performance include professional trainings, staff capacity building, possession of exemplary skills and ability, service without fear or favour, and believing in delivery of quality service. The findings of the study will be useful to the security organs in the National Police Service and other security organs within the Republic of Kenya.
\end{abstract}

Key Words: Strategic Leadership, Management Competencies, Corporate Culture, Stakeholder Involvement, Ethical Practices, Organizational Performance, Directorate of Criminal Investigations

DOI: $10.35942 / i j c a b . v 3 i V .69$

Cite this Article:

Bose, E., \& Ndegwa, P. (2019). Strategic Leadership and Organizational Performance of Directorate of Criminal Investigations in Nairobi County, Kenya. International Journal of Current Aspects, 3(V), 166-185. https://doi.org/10.35942/ijcab.v3iV.69 


\section{Introduction}

The role of leadership in ensuring high performance in organizations and employee organizational commitment cannot be overemphasized. Leadership is often seen as a key factor in coordinating and aligning organizational processes (Lewis, Packard, \& Lewis, 2007) Organizational leadership is an issue that is gaining widespread apprehension and taking center stage discussion in virtually all boardrooms and which has initiated heated debate and thousands of empirical studies in the past one century. The quality of an organization's top leaders is a critical influence on its overall effectiveness and continuing adaptability. Yet little current research examines strategic leadership within the context of management competencies, corporate culture, stakeholder involvement, and ethical practices. Despite the research efforts, literature appears disconnected and perhaps this is due to the fact that studies in strategic leadership are context free (Zaccaro Klimoski, 2001). Kjelin, (2009) explains strategic leadership as an ability of an organization to anticipate, envision, and maintain flexibility, and empower others to create a strategic chance and a viable future of the organization. Further, organizational leadership is widely recognized as an important dual focused management approach that works towards what is best for employees and the management in order to sustain organizational survival and growth (Surya, 2015).

The national security organs in Kenya as enshrined in chapter14 of the Kenyan constitution include; the Kenya Defense Forces (KDF), the National Intelligence Service (NIS), and the National police service (NPS). The Kenya Defense Forces (Army, Air Force and Navy) commonly known as the KDF was established under the Armed Force Act, Chapter 199 of the Law of Kenya, with the responsibility of defending the country under overall control and direction of the Defense Council. Its key responsibility includes defending the country against armed external aggression and supporting the civil authority in the maintenance of order. The National Intelligence Service (NIS) was established under the NIS act No 1998 and is responsible for collecting/analysing information and gathering intelligence on national security for purposes of detecting and identifying any threat to national security (Kiraithe, 2011). The National Police Service faces unprecedented pressure to improve its services to the people of Kenya. Following post-election violence in 2007, members of public felt that working conditions of police left a lot to be desired. Allegations of police using excessive force left the pubic with harbored bitterness. In 2009 a task force on police reforms appointed by his Excellency (Rtd) president Mwai Kibaki was formed under the chairmanship of Hon. Mr. Justice (Rtd) Philip Ransely. The taskforce was mandated to make a comprehensive analysis of the policies, legal framework, and working environment in which police work. After the promulgation of the new constitution in 2010 major changes were effected on police work. Some of these changes include: creation of the IGs position who is the overall commander of KPS, APS and DCI.CID was also changed to DCI and the birth of IAU and IPOA became a reality. These oversight bodies were not only to benefit police but also give public confidence that complains could now be handled in a just and fair manner. In the last eight years, several changes have been witnessed in the National Police Service relating to the police training curriculum, recruitment of personnel, pay structure, implementing of performance quality management systems, modern equipment that has seen automation and extensive utilization of ICT in policing and better working conditions however, the efficiency does not match the changes (Ransley Report 2009).

The National Police Service has three main units under it which include the Kenya police, Directorate of Criminal Investigations and the Administration Police. According to DCI (2017), a five year strategic plan (2017-2022) has mapped out the Strengths, Weaknesses, Opportunities and Threats (SWOT) of the crucial department of the criminal justice system due to the non-performance challenges and calls for reform. Among the threats identified in 
the plan include terrorism, money laundering, cyber-crimes, and political interferences with service delivery, organized criminal gang and unequal access to opportunities among others. Despite the challenges the directorate has made a number of achievements which include the automation of the criminal registry through Automated Palm and Fingerprints Identification System (APFIS) project. In addition, the application of Police Clearance Certificate can now be done online through the e-Citizen portal after processing, the certificate is uploaded on the same portal for the applicant to download and print. The Integrated Ballistics Identification System has also been installed and is helping in expediting the process resolving of cases where firearms have been used in the commission of crimes. The IG of Police looks forward to leading police officers who are devoted, dedicated to discharging their duties, freely interact amongst themselves and the public, know their professional code of conduct, hold high integrity levels, and their work is appreciated by the society at large (Ransley Report, 2009). These strategies are part of the police reforms and also the goodwill of the Kenyan population. An international survey undertaken in 2013 described Kenyans as the most optimistic people. This optimism can be enhanced among the Kenyan people by implementing the proper strategies in the National Police Service.

Strategic leaders ought to look forward in time to set directions for the organizations (Arnott, 1995). Their power is increased when they scan and cope with the critical sectors of their environment (Hambrick, 1981). Strategic leaders make and communicate decisions for their organization's future (Zaccaro, 2006). They formulate the organization's goals and strategies, develop structures, processes, controls and core competencies for the organization, and manage multiple constituencies. Strategic leaders are also tasked with choosing key executives, grooming the next generation of executives, providing direction with respect to organizational strategies, maintaining an effective organizational culture, and sustaining besides coming up with a system of ethical values. Moreover, strategic managers serve as the representative of the organization to government and organizations as well as constituencies with mandate to negotiate with them. Such strategic leadership must be able to deal with ambiguity, complexity, and information overload requiring adaptability and a sense of timing (Boal and Hooijberg, 2000). Provision of strategic leadership is a fundamental responsibility for the CEO and for many other senior executives (Farkus and De Backer, 2006). They need to understand the vibrancy of their available markets, the products and services that can serve those markets advantageously, balance sheets and the availability of capital, how to optimize the interests of the various organizational constituencies, how to manage change in good times and bad times, how to use authority and accountability, and how to shape an effective management team of diverse competencies and interests.

\subsection{Strategic Leadership}

Strategic leadership is an ability of firms to anticipate, envision and maintain flexibility, and empower others to create a strategic chance and a viable future of the organization (Kjelin, 2009). Guillot (2006) defines strategic leadership as the ability of an experienced, senior leader who has wisdom and vision to create and execute plans and make consequential decisions in the volatile, uncertain, complex and ambiguous strategic environment. Montgomery (2008) argues that, few leaders allow themselves to think about strategy and the future. Leaders should give direction to every part of the organization - from the corporate office to the loading dock. Strategic leadership is therefore the ability of the leaders to create and re-create reasons for the organization's continued existence. The leader must have the ability to keep one eye on how the organization is currently adding value and the other eye on changes, both inside and outside the organization, that either threaten its position or present some new opportunity for adding value. Some researchers belief that strategic leadership concept may become the most apt concept to embracing better value driven culture in public 
sector in the era of the $21^{\text {st }}$ century (Draft \& Pirola-Merlo 2009; Jing \& Avery 2008; Ireland and Hitt 2005). Leadership in public sector tend to face the great challenges due to the prominent rule-based and too bureaucratic leadership styles, non-performance based Human Resource Management (HRM) culture, and lack of innovative management practices. Several key roles of strategic leadership can be offered as strategies to sustain public organization performance outcome (Ireland \& Hitt, 2005). The DCI strategic plan 2017-2022 stipulates the direction the directorate leadership should take and necessities for the success of the objectives of the arm of the National Police Service. The influence of strategic leadership on organizational performance of the DCI operations in Nairobi City County, Kenya was being sought by this study.

\subsection{Organization Performance}

Organizational performance is an organization's ability to achieve its goals by using resources in an efficient and effective manner (Daft \& Marcic, 2016). In this view, achieving superior organizational performance is not a question of luck as it must be determined through strategic leaders' practices (Daft, 2011). Any challenge facing not-for-profit organizations require strategic leaders to make the vital decision on how to move about it. Strategic leadership practices, skills and knowledge, not-for-profit organization leaders can realize the mission and objectives of their organizations. However, it was noted by Sink and Tuttle (1989) that performance should not be taken only as a monetary idea. The researcher further recommended that non-monetary performance should also have a severe attention predominantly in the service sector (Fitzgerald, Johnston, Brignall, Silvestro, \& Voss, 2011; Kaplan \& Norton, 2012) which was generally supported by scholars and researchers because it places emphasis on long term achievement and customer's satisfaction that are duly measured (Kaplan \& Norton, 2006, 2001Lynch \& Cross, 2011;Otley, 2008;Van Veen-Dirks \& Wijn, 2012). It was recommended by Laitinen (2003) that there should be the same attention given to both monetary and non-monetary measurement of performance so as to assist managers in making concurrent review for better decision making

Every organization exists to achieve a particular goal. Performance is the final achievement of an organization and contains a few things, such as the existence of certain targets, has a period of time in achieving these targets and the realization of efficiency and effectiveness (Gibson \& James 2010). Thus, performance refers to ability of an enterprise to achieve such objectives as high profit, quality product, large market share, good financial results, and survival at pre-determined time using relevant strategy for action (Koontz and Donnell, 1993). Performance provides the basis for an organization to assess how well it is progressing towards predetermined objectives, identify areas of strength and weakness and decide on the future initiatives with the goal of how to initiate performance improvement (Van weele, 2006). Performance includes multiple activities that help in establishing the goals of the organization, and monitor the progress towards the target (Johnson, Yip, Devinney \& Richard 2009). Rowley (2011) used both financial and non-financial indicators. The financial indicators were a percentage growth in sales, labelled as sales growth and percentage profit margin labelled as profitability. They used public image and goodwill, quality of services and efficiency of operations as the non-financial indicator.

\subsection{Directorate of Criminal Investigations in Kenya}

Directorate of criminal investigation is an investigative institution under the national police service it is responsible for investigating complex cases. It is commonly referred to by the initials DCI. It is headed by a Director who reports to the IG of Police. Due to the sensitivity of the position, the Director is appointed by the President of Kenya. The DCI headquarters are located on Kiambu Road, Nairobi. Under the direction, command and control of the 
Inspector General, the Directorate of Criminal Investigations collects and provides criminal intelligence, undertakes investigations on serious crimes including homicides, narcotics, money laundering and economic crimes, maintains law and order, detects and prevents crime, apprehends offenders, maintain criminal records, coordinates Interpol Affairs and carries out investigation of matters that may be referred to it by the IPOA. The mandate of the Directorate of Criminal Investigations as derived from Part V, Section 28 and 35 of the National Police Service Act 2011 is to conduct criminal investigations and all other aspects incidental thereto. The main duties of the DCI include investigating and apprehending those involved in terrorism, cyber-crime, land fraud, drug related issues, financial and hi-tech crimes and serious crimes. Strategic leadership therefore is significant in ensuring the directorate delivers on its mandate effectively and efficiently. The study seeks to establish the relationship between strategic leadership and organizational performance of the DCI in Nairobi City County, Kenya.

\section{Statement of the Problem}

All organizations exist as open systems. This means that they impact and are impacted by external conditions largely beyond their control. The security sector in Kenya has been faced with a myriad of challenges ranging from low public confidence, poor leadership, incompetence, inefficiency and low quality services. It thus calls for the managers to look beyond the limits of the organization's operation and formulate appropriate strategies in order to be able to attain their set targets and goals (Pearce \& Robinson, 2002). Though most organizations are able to effectively formulate innovative strategic plans, very few of these strategies are implemented. This has seen numerous studies and research being conducted so as to determine the challenges faced during strategic leadership. Limited studies have been done to establish the challenges of strategic leadership at the National Police Service of Kenya and more specifically the DCI. Other problems that affect DCI performance includes facilities, limited funding and above all poor strategy formulation and implementation. Strategic leadership is the leader's ability to anticipate, envision, maintain flexibility, and empower others to create strategic change as necessary. From a study that investigated the factors influencing police officers' perception of police reforms: a case of Kenya Police Service, Nairobi County; training had the highest effect on perception of police reforms in Kenya, seconded by staffing followed by recruitment, then terms of service and legal structure having the lowest effect on the perception of police reforms in Kenya (Kingori, 2013). Kiraithe (2011) studied management of strategic change at Kenya Police Service. He noted that resistance to change was still a major barrier to successful change management. Chtalu (2014) examined the challenges affecting police reforms within Nairobi County. The study revealed that police reforms had not elicited noticeable recognition from the police officers.

Aosa (2012) carried out an empirical investigation of aspects of strategy formulation and implementation within large, private manufacturing company. The study investigated strategic management practices in Kenya. His findings were, implementation takes longer time that was originally allocated, uncontrollable factors in the external environment, unforeseen obstacles, surfacing during the implementation that had not been identified, competing activities among others as challenges of strategy implementation. However this study was carried out in large manufacturing companies while the current study was carried out in DCI. Awino (2000) studied the effectiveness and problems of strategy implementation of financing higher education in Kenya. His findings were that policy framework was inadequate. Mutemi (2014) examined the performance of the police reservists in Kenya. The study identified and prioritized legal/policy gaps on the basis of their level of threat to effective reservists' performance. These include ambiguity on the procedure on remunerative 
allowances, lack of clear guidelines on recruitment and deployment, inadequate guidelines on supervision and control, lack of clear guidelines on training, lack of guidelines on medical cover, injury and life compensation. Karanja, Were and Leah (2012) undertook a study on the factors influencing service delivery in the National Police Service: a case study of Kenya police in Nairobi county. The study noted that adoption of ICT by the police service has a positive impact on service delivery to citizens. Strategy implementation guides and gives details on strategic leadership in an organization. The study sought to find out the influence of strategic leadership on organizational performance of DCI in Nairobi City County.

\section{Objectives of the Study}

The main research objective was to establish the influence of strategic leadership on organizational performance of the DCI in Nairobi City County, Kenya.

The specific objectives of the study were;

i. To establish the influence of management competencies on the organizational performance of the DCI in Nairobi City County, Kenya.

ii. To examine effect of corporate culture on organizational performance of the DCI in Nairobi City County, Kenya.

iii. To establish the influence of stakeholder involvement on the organizational performance of the DCI in Nairobi City County, Kenya

iv. To determine effect of ethical practices on the organizational performance of the DCI in Nairobi City County, Kenya

\section{Theoretical Review}

The study was anchored on three theories that explain strategic digital marketing and performance in organizations. They include; the trait leadership theory, path-goal leadership theory and the transformation leadership theory.

\subsection{Trait Leadership Theory}

The major works behind the trait theories are by Stogdill in 1948 and in 1974; Mann in 1959; Kirkpatrick in 1986 and Lord in 2011. These studies show that trait theories were prominent in in the early and late 90s. During the period between 1920's and 1930's, a lot of leadership research focused on the traits that differentiate leaders from non-leaders. Trait theory is one of the earliest leadership theories and it focuses on what an effective leader is and not what an effective leader does. According to Bhatia (2009), trait theory postulates that there are sets of traits and characteristics that are associated with successful leaders. The theory is anchored on collection of characters of many leaders both successful and unsuccessful the resulting list of traits are then compared to those of potential leader. The trait theory focuses on the physiological, demographic, and social economic, personality, self-confidence, intellective sociability, interest, abilities, and personality traits aggressiveness. It further states that Empirical studies supporting trait theory have found evidence that there are traits that contribute to an organization's effectiveness and performance (Northouse, 2013). The list of leader traits, however, is huge and continues to grow as leaders emerge core traits identified as desirable in this theory are: the desire to achieve, a desire to lead others, honesty and integrity, self-confidence, cognitive ability, charisma, creativity and knowledge of business. Despite numerous studies on the diversity of leadership traits, certain criticisms have been levelled out on the trait leadership theory (Northouse, 2013).

For instance it is argued out that leadership can be learned, nurtured and not necessarily an inborn thing as has been the case in human history where some very successful leaders 
emerged to diverse situations. Another criticism is that there is nothing inborn, divine, or mysterious as leadership qualities (Northouse, 2013). The point is that leaders do not succeed because they possess certain traits in isolation with other factors (Bhatia, 2009). There is evidence in the literature that individual traits matter although leadership effectiveness can also be attributed to other environmental factors (Bhatia, 2009; Northouse, 2013). Following these arguments, Bhatia (2009) posits that leadership quality and traits are not sufficient for achieving organizational effectiveness.

Perhaps in an attempt to conclude the discussion on traits, Northouse (2013) isolated five traits which lead to organizational transformations namely intelligence, self-confidence, determination, integrity, and sociability. These traits are interesting because they link well with the strategic leadership practices. The traits cited out in many trait theories link to strategic leadership practices in regards to leader characteristics, abilities, and effectiveness in a responsibility or organization. Understanding the role of leadership traits in strategic leadership practices is important especially where success is not dependent on a single factor. This is more important because the traits a specific leader possesses qualifies why he or she is an important asset in the organizational performance. The leader and subsequently the leadership practices add to competitiveness of an organization which is required in the security sector also. This theory contributes to the tenets for successful strategic leadership practice that underlie a leader's characteristics, abilities, and knowledge which drive an organizations' performance.

\subsection{Path-Goal Leadership Theory}

The path-goal leadership theory is credited to the works of Martin G. Evans in 1970. This theory was refined in the following year by Robert J. House in 1971. The proponents of the path-goal theory argue that leaders' behaviour is contingent to the satisfaction, motivation and performance of subordinates. Followers are motivated in a task by the high level of selfefficacy, belief that their efforts result in a certain outcome or reward and belief that an outcome or reward is worthwhile (Bhatia, 2009). The role of the leader in this theory is to motivate followers by rewarding performance and goal accomplishment. According to Northouse (2013) effective leadership occurs when the leader accurately diagnosis the development level of subordinates in a task situation and then exhibits the prescribed leadership style that matches that situation. Dixon and Hart (2010) argue that leaders who lead by means of path-goal leadership reward and encourage their followers towards goal achievement. Path-goal theory enables leaders to discern the right strategic direction for the employees and the organization. Malik (2012) opine that this theory predicts the leader behaviour which is essential for achieving subordinates' motivation and which is also linked to organizational performance. In line with this argument, Northouse (2013) emphasizes to match leader behavior with subordinates characteristics along with work environment.

Implementing path-goal theory increases subordinates' motivation by clarifying the path towards which organizational performance is possible. Strategic leadership practice has been viewed as being able to contribute significantly and positively towards achieving organizational performance by motivating others to pursue the same strategic direction. This theory was relevant in this study for its focus on the role of the leader in motivating subordinates towards achieving an organization's goal. Path-goal theory is argued to be result oriented and equally strategic leadership practices are result-oriented. Therefore there is a clear link with path-goal theory and strategic leadership practices as both types of leadership are result-oriented. This theory supports the argument that strategic leadership practice has an effect on organizational performance; therefore, it needs to be established. 


\subsection{Transformational Leadership Theory}

The origin of transformational leadership is traced to the research of James McGregor Burns in 1978 which was later expounded by Bernard Bass in 1985. Transformational leadership blends the behavioural theories with trait theories. This theory evolved from a study by Bernard M. Bass, entitled, "Leadership Performance Beyond Expectations", in which transformational leadership was characterized by increasing subordinates' awareness of the importance of their tasks and performing well, making subordinates aware of their needs for personal growth, development, and accomplishment, and motivating subordinates to work for the good of the organization. Transformational leaders appeal to followers' ideals and moral values and inspire them to think about problems in new ways (Northouse, 2013). According to Bertocci (2009), transformational leadership theory provides a rational approach as through it a leader is able to observe how leaders actually motivate and reward followers for achieving the organizational vision. This theory is intrinsically related to the goal of strategic leadership which is to anticipate, envision, maintain flexibility, and empower others to create the strategic change necessary for the organization.

Understanding transformational leadership in leadership studies is important because this leadership is said to instill feelings of confidence, admiration and commitment in the followers, stimulates followers intellectually, arouses new of thinking about problems, uses contingent rewards to positively reinforce performances, takes and commits people to action and converts followers into leaders (Northouse, 2013; Daft, 2013). Empirical studies on leadership-organization relationship have found evidence that transformational leadership predicts organizational performance which is a major concern in this study. Bakar and Mahmood (2014) revealed that there was significant and positive relationship between transformational leadership and performance. According to Daft (2013), transformational leadership leads to organizational performance. Kissi, Dainty and Tuuli (2013) also noted that transformational leadership had positive and significant relation with project performance. Transformational leadership contributes to understanding how strategic leaders can align organization's mission, strategy, structure, and culture to promote desired organizational performance (Daft \& Marcic, 2016). Similarly, Seyhan (2013) revealed that transformational leaders have a significant effect on the organizations' mission and its accomplishments.

The importance of transformational leadership in strategic leadership practices regards to the leaders' confidence in the organizations' vision, personal responsibility, and sense of purpose, determination, persistence, and trust in employees and emphasis for accomplishments of goals rather than failures (Gill, 2011). Bekele and Darshan (2011) support this argument in that transformational leadership increases subordinates' job satisfaction which in turn increases organizational performance. Likewise, McGough (2010) avers that transformational leaders are responsible for shaping the organizations' future. Understanding the role of transformational leadership in organizational performance serves as a clarification for why not-for-profit organizational leaders need strategic leadership practices to transform their organizations towards better performance. In the context of this study, transformational leadership theory brings out the link between leadership flexibility and innovation in the sense of appropriate orientation in defining tasks and managing interrelationships in the organization. Transformational leadership provides important aspects of strategic leadership practices like concern for human capital.

\section{Empirical Review}

This covers the analysis and evaluation done by other authors or researchers in the field of strategic leadership and performance among organizations and how significant their 
relationship has been established to be. The literature reviewed was meant to establish the research gap to justify this study and also to show the connection with the theories reviewed above.

\subsection{Management Competencies and Organizational Performance}

Core competencies are the resources and capabilities that serve as a firm's source of competitive advantage. Typically, core competencies relate to the functional skills of an organization, such as manufacturing, finance, marketing, and research and development. Core competencies allow organizations to produce and deliver products that have unique benefits and value for customers (Hamel and Prahalad, 2013). For example, Philip Morris has developed a core competence in its marketing function, especially in terms of promotion skills. (Hitt and Keats, 2012 ). As strategic leaders, corporate managers make decisions intended to help their firm develop, maintain, strengthen, leverage, and exploit core competencies. Exploiting core competencies involves sharing resources across units. In general, the most effective core competencies are based on intangible resources, which are less visible to competitors because they relate to employees' knowledge or skills. Effective strategic leaders promote the sharing of intangible resources across business units in their firms (Hitt and Keats, 2012). In many large, diversified firms, core competencies are developed and applied across different units in the organization (economies of scope) to create a competitive advantage. Miller Beer, for example, has applied marketing and promotion competencies across its multiple businesses (Maruca, 1994). In many multinational corporations, the development, nurturing, and application of core competencies also facilitate managing complex relationships across business operating in different international markets. Whirlpool has emphasized competency across country borders (Lei, Hitt, and Bettis, 1996).

Controls are necessary to help ensure that firm's achieve their desired outcomes (Redding, 2002). These are formal information based procedures used by managers to maintain or alter patterns in organizational activities. Controls help strategic leaders build credibility, demonstrate the value of strategies to the firm's stakeholders and promote and support strategic change (Shields, Deng and Kato, 2000). According to Hitt \& Hoskisson (2006) the organization's capacity to control, monitor and track progress for programmes, projects and monthly results need to be well established. Leaders are therefore responsible for the development and effective use of two types of internal controls, namely strategic controls and financial controls. Strategic controls require information-based exchanges among the CEO, leadership team members, and employees. To exercise effective strategic control, leaders must acquire deep understanding of the competitive conditions and dynamics of each of the units or divisions for which they are responsible. Exchange of information occur through both informal, unplanned meetings and interactions scheduled on a routine formal basis. The effectiveness of strategic controls is increased substantially when strategic leaders are able to integrate disparate sets of information to yield competitively relevant insights (Hitt \& Hoskisson, 2006). Financial controls focuses on short-term financial outcomes (Laverty, 2006).

The balanced scorecard is a framework that firms can use to verify that they have established both strategic and financial controls to assess their performance (Kaplan and Norton, 2001). The underlying premise of the balanced scorecard is that firm's jeopardize their future performance possibilities when financial controls are emphasized at the expense of strategic controls (Becker, Huselld and Ulrich 2001). In that financial controls provide feedback about outcomes achieved from past actions but do not communicate the drivers of the firm future performance. Thus an overemphasis on financial controls could promote organizational 
behavior that has a net effect of sacrificing the firm's long-term value creating potential for short-term performance gains (Kaplan and Norton, 2012). An appropriate balance of strategic controls and financial controls rather than an overemphasis on either, allows firms to effectively monitor their performance. The four perspectives are integrated to form the balanced scorecard framework are: financial, customer, internal business processes, and learning and growth (Mische 2001).

\subsection{Corporate Culture and Organizational Performance}

Corporate culture refers to the core values shared by all or most employees. It consists of a complex set of shared ideologies, symbols, and values that influence the way the firm conducts its business. Corporate culture is the social energy that drives or fails the organization (Barney, 1986). Strategic leaders must develop and nurture an appropriate culture, one that promotes focused-learning and human development, the sharing of skills and resources among units in the firm, and the entrepreneurial spirit important for innovation and competitiveness. An appropriate corporate culture can encourage an entrepreneurial spirit, foster and facilitate a long-term vision, and create an emphasis on strategic actions linked with the production of high-quality goods and services. Corporate culture helps regulate and control employee behavior (Lei, Hitt, and Bettis, 2010). Changing culture is more difficult than sustaining it. But effective strategic leadership involves recognizing the need to change the culture and implement the changes. Restructuring may provide an appropriate time to effect a change. In the 2010s, Lee Iacocca succeeded in implementing major changes in Chrysler's corporate culture (Hitt, Hoskisson, and Harrison, 2011).

Organizational culture consists of a complex set of ideologies, symbols and core values that are shared throughout the organization and influences the way business is conducted. Evidence suggests that a firm can develop core competencies in terms of both capabilities it possess and the way the capabilities are leveraged by strategies to produce desired outcomes. In other words, because the organizational culture influences how the firm conducts its business and it helps regulate and control employees' behavior, it can be a source of competitive advantage (Gupta and Govindarajan, 2000). According to Zellner (1997) some organizational cultures operate in a heavy-handed and competitive manner with little room for mistakes and no patience with the expression of discontent. It is very important to remember that cultural norms can transmit effective and healthy patterns of behaviour as well. Drucker (1997) argues that every organization has a culture that helps to shape and define the context in which an individual's behaviour is perceived and judged. The emphasis a leader gives is influenced by the organization's culture and the formal and informal reward systems that reinforce that culture. Often the most powerful factors are subtle and difficult to observe unless one is part of the system. The powerful rules that drive and hone leader behaviour are often the unwritten and unspoken threads that are woven into the fabric of dayto-day life. Employees come to know these subtleties by how they are rewarded or punished. The rewards and punishments are themselves often subtle. They shape the behaviour and are most powerful when they are outside the leadership's awareness (Drucker, 1997).

\subsection{Stakeholder Involvement and Organizational Performance}

Stakeholders refers to those concerned or affected when ideas proposals or observations are observed or implemented. Dee Le (2013) indicates that change is inevitable and any effort to manage change is uniquely complex. Organizational Change Management (OCM) is centered on managing the people side of change, and there are some key strategies you can use to involve your stakeholders throughout the process so that change is empowered, not imposed. The goal is to involve stakeholders in each and every change so that they are empowered to guide its success. To achieve the greatest level of success with your changes, focus on 
opportunities to involve leadership and stakeholder collaboration from the start. Empowering change by engaging early on with the people directly affected by the change and communicating its benefits increases the likelihood of acceptance. Even the smallest lack of awareness or indifference to your stakeholders can quickly manifest into a problem that will negatively impact your business. Being sensitive to your stakeholders can bring about a change in a progressively evolutionary way, rather than a reactionary one. Eun Jin Hwang (2005) studied stakeholder involvement and financial performance in South Korean apparel retail stores. Perceived market turbulence positively affected stores' market-orientation strategies and functional specialization. Market orientation strategy positively affected stores' functional specialization and centralization of decision making. Intelligence generation positively affected satisfaction with store performance relative to other Korean retail stores and relative to key competitors, and response implementation positively affected satisfaction with store performance relative to other Korean retail stores. Some positive relationships were found between perceived environmental uncertainty and top management's willingness to adapt to a changing market. A major conclusion was that Korean apparel stores' top managers did not view environmental conditions as important influences on their stores' performance, although their perceptions of environmental uncertainty affected their stores' strategic management in such terms as response design, intelligence generation, and intelligence dissemination.

Petsmaster (2010) focused on the relationship between strategic management practices (SMPs) and the financial performance of multinational corporations (MNCs) in emerging markets. The study adopted a quantitative research approach where relevant MNC data was collected using a specially designed online questionnaire. Furthermore the study used the descriptive approach, which critically reviews the secondary data from relevant available literature. The study found that for MNCs with comprehensively adopted and implemented the SMPs framework their financial performance continues to improve year on year, depicting a positive relationship between SMPs and overall financial performance of MNCs with business interests in emerging markets. Nguluu (2006) studied the relationship between strategic management and performance of tea-manufacturing firms in Kenya. The major finding of the study was that the level of practice (state) of strategic management had a direct positive contribution to the performance of the organizations studied. Those organizations that did not practice strategic management performed relatively poorly compared to those that practiced. Emerging strategic management knowledge was therefore making a major contribution to the economic development of the nation.

\subsection{Ethical Practices and Organizational Performance}

Another important strategic leadership practice variable is ethical leadership practice. Ethical leadership practices in organizations are issues demanding the attention of researchers and practitioners' alike. Ethical practices refer to the code of conduct that stipulates behaviour within a given institution. Ethical practices come from the kind of leadership available in an organization. Hence for an ethical culture to be inculcated in the organization, the leadership must be in the forefront. In this study, ethical practices are discussed in the context of ethical leadership. Effective strategic leaders emphasize ethical practices within their organizations, and seek to infuse them through the organizational culture. The ethics that guide the individual actions are based on principles formed by long-term influences that extend beyond the organization. However, organizations can shape and control employees' and managers' behavior through formalized rules, economic rewards and sanctions, and the values and norms that represent corporate culture (Sinclair, 2013). 
To the extent that employees and managers share a common set of ethical principles, there is a strong likelihood that ethical practices will be observed. For example, top executives of the pharmaceutical firm Johnson \& Johnson claim that one of the major sources of their success was their firm's culture, which emphasizes ethnical conduct even across international boundaries (Sinclair, 2013). GE's culture also emphasizes values that underlie important ethical principles. For instance, GE's CEO confirms that integrity is an important value for the company and its employees (Hitt, Ireland, and Hoskisson, 1995). Mihelič, Lipičnik, and Tekavčič, (2010) notes that ethical practices concern strategic leaders' ability to be humble, to have concern for the common good, strive for fairness, taking responsibility and showing respect for each individual. According to Hale (2013), ethical practices in not-for-profit organizations have been associated with greater reputation, trust, confidence and above all organizational performance. Toor and Ofori (2009), ethical practices play a critical role in mediating organizational culture and employee performance. Alshammari, Almutairi, and Thuwaini (2015) notes that firm successes are attributable to sound ethical practices which equally contributes significantly to organizational performance.

The relevancy of ethical leadership practice has been on the increase as a result of several major scandals in the form of fraud, corruption and mismanagement of organizations'/firms' resources (Hsin-Kuang, Chun-Hsiung, \& Dorjgotov, 2012). Neubert, Wu, and Roberts (2013) argue that the collapse of many organizations points to failure in strategic leadership practices. Engaging in ethical leadership practices in organizations is one of the key strategic leadership practices that leads to organizational performance. Piccolo, Greenbaum, Hartog, and Folger (2010) suggests that strong ethical practices is responsible in motivating employees in organizations to be passionate about ethical practices which leads them to achieve firm performance. Policies and procedures incorporate the key ethical practices needed to ensure compliance in an organization. Government security organizations such as the DCI need also to ensure that they have clear ethical principles to guide certain operations in the organization such as accounting principles, procurement, hiring, advertising, promotions and so forth which all ensure public trust on the organization.

\section{Conceptual Framework}

The independent variable was strategic leadership principles which include core competencies, corporate culture, stakeholder involvement and ethical practices while dependent variable was performance of the DCI in Nairobi City County. 
Independent Variables

Dependent Variable

\section{Strategic leadership}

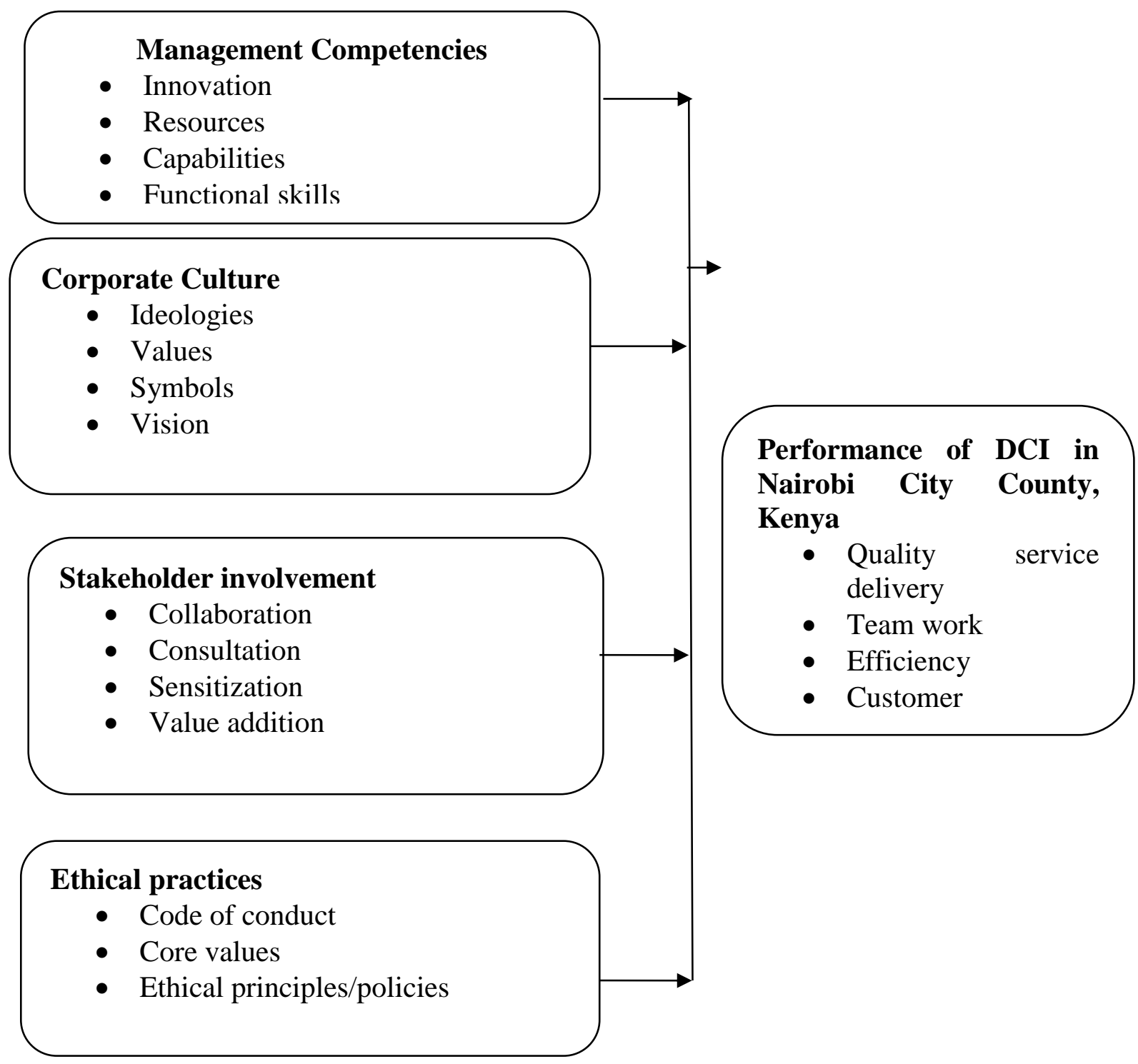

\section{Figure 1: Conceptual Framework}

\section{Research Methodology}

The study adopted a descriptive design which Mugenda and Mugenda (2003) is described as a research design which is a systematic, empirical inquiring into which the researcher does not have a direct control of independent variable as their manifestation has already occurred or because the inherently cannot be manipulated. A population is a well-defined or set of people, services, elements, and events, group of things or households that are being investigated. The target population for study was the offices at the DCI in Nairobi City County including senior management, middle level management and lower level manage. According to the National Police Service (2018), there are 255 senior officers deployed at the 10 units of the DCI in Nairobi City County. This study therefore used a sample of 255 respondents drawn from all the 10 units of the Directorate of Criminal Investigations in Nairobi City County. 
Primary data was collected by the help of a semi structured questionnaire. The close-ended questions provided more structured responses to facilitate tangible recommendations while the open-ended questions provided additional information that was be captured in the closeended questions. The study used primary data which was collected through questionnaires that was administered to the senior officers at the DCI in Nairobi City County.

The questionnaires were administered to the respondents through a drop and pick method due to the nature and mode of work of the officers and tight schedule. Fully completed questionnaires were collected and call-backs made as necessary. Confidentiality of the respondents was guaranteed through an assurance letter which would be issued with each questionnaire. After data collection, a thorough check was done on the questionnaires before coding and using Statistical Package for Social Sciences (SPSS). The primary data collected through questionnaires was analyzed using excel to obtain existing correlations. The correlations 1 informed the researcher on existence or non-existence of a relationship between the strategic leadership approaches and organizational performance. Quantitative data was presented in through tabulation, percentages, mean, standard deviation and frequencies. A multivariate regression model was applied to determine the relative importance of each variable to the study. Mugenda and Mugenda (2003) noted that multiple regression attempts to determine whether a group of variables together, predict a given depended variable.

\section{Data Analysis Results}

Inferential statistics were based on correlation between variables, coefficient of determination (R-squared), analysis of variance (ANOVA) as well as regression model.

Table 1: Correlation Coefficients

\begin{tabular}{|c|c|c|c|c|c|c|}
\hline & & 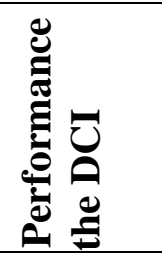 & 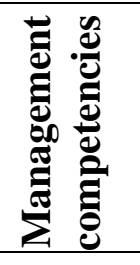 & تِّ & 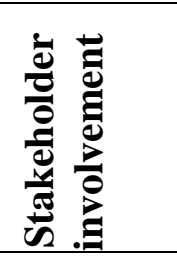 & 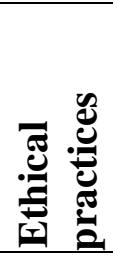 \\
\hline \multirow[t]{2}{*}{$\begin{array}{l}\text { Performance of } \\
\text { the DCI }\end{array}$} & $\begin{array}{l}\text { Pearson Correlation } \\
\text { Sig. (2-tailed) }\end{array}$ & 1.000 & & & & \\
\hline & $\mathrm{N}$ & 61 & & & & \\
\hline \multirow{3}{*}{$\begin{array}{l}\text { Management } \\
\text { competencies }\end{array}$} & Pearson Correlation & $.455(* *)$ & 1.000 & & & \\
\hline & Sig. (2-tailed) & - & & & & \\
\hline & $\mathrm{N}$ & 61 & 61 & & & \\
\hline \multirow{3}{*}{$\begin{array}{l}\text { Corporate } \\
\text { culture }\end{array}$} & Pearson Correlation & $.676(* *)$ & 0.222 & 1.000 & & \\
\hline & Sig. (2-tailed) & - & 0.085 & & & \\
\hline & $\mathrm{N}$ & 61 & 61 & 61 & & \\
\hline \multirow{3}{*}{$\begin{array}{l}\text { Stakeholder } \\
\text { involvement }\end{array}$} & Pearson Correlation & $.606(* *)$ & $.256(*)$ & $.298(*)$ & 1.000 & \\
\hline & Sig. (2-tailed) & - & 0.047 & 0.020 & & \\
\hline & $\mathrm{N}$ & 61 & 61 & 61 & 61 & \\
\hline \multirow[t]{3}{*}{ Ethical practices } & Pearson Correlation & $.691(* *)$ & 0.246 & $.541(* *)$ & $.369(* *)$ & 1.000 \\
\hline & Sig. (2-tailed) & - & 0.056 & - & 0.003 & \\
\hline & $\mathrm{N}$ & 61 & 61 & 61 & 61 & 61 \\
\hline
\end{tabular}


Table 1 shows the correlation coefficients for each pair of variables. All correlations were found to be positive indication that each variable (whether dependent or independent) had a positive relationship with every other with the highest correlation recorded between ethical practices and performance of DCI (0.691) while corporate culture and management competence depicted the least correlation (0.222), a relationship that was found to be insignificant $(\mathrm{p}$-Value $=0.08)$ at the 0.05 level (2-tailed) significant level. All other correlations were significant with $\mathrm{p}$-Value being less or equal to 0.05 at 2-tailed test.

Table 2: Coefficient of Determination

\begin{tabular}{lllll}
\hline Model & R & R Square & Adjusted R Square & $\begin{array}{l}\text { Std. Error of the } \\
\text { Estimate }\end{array}$ \\
\hline 1 & $.872(\mathrm{a})$ & 0.760 & 0.743 & 0.225
\end{tabular}

a

Predictors: (Constant), Ethical practices, Management competencies, Stakeholder involvement, Corporate culture

To determine the extent to which the independent variables collectively explained any change in performance of DCI, R-squared was computed and found to be 0.76 as shown in Table 4.7. This implies that for any positive change by one unit in performance of DCI, the four independent variables assessed in this study (that is, ethical practices, management competencies, stakeholder involvement, and corporate culture) positively explain $76 \%$ of that change. The remaining 24 percent is explained by other variables not considered in this study. Findings of this study are consistent with Trait Leadership theory that postulates that, there are sets of traits and characteristics that are associated with successful leaders (Bhatia, 2009. The trait theory focuses on the physiological, demographic, and social economic, personality, self-confidence, intellective sociability, interest, abilities, and personality traits aggressiveness. These traits in the current study can be construed as the ethical practices, management competencies, stakeholder involvement, and corporate culture as facilitated by strategic leaders.

Table 3: Analysis of Variance

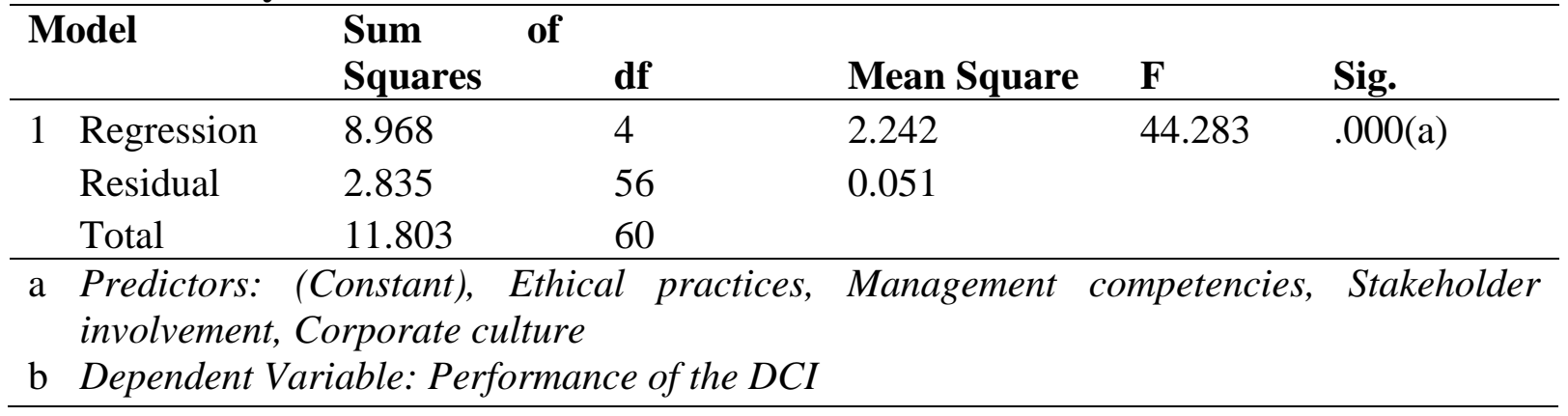

Table 3 presents analysis of variance where F-Value was found to be 44.283 which display a significant relationship between the independent variables and the dependent variable. This is further confirmed by $\mathrm{p}$-Value $=0.000<0.05$. Therefore ethical practices, management competencies, stakeholder involvement, and corporate culture at their composite level positively and significantly influence performance of DCI. These findings confirm that, there are traits that contribute to an organization's effectiveness and performance (Northouse, 2013). The list of leader traits, however, is huge and continues to grow as leaders emerge core traits identified as desirable in this theory are: the desire to achieve, a desire to lead 
others, honesty and integrity, self-confidence, cognitive ability, charisma, creativity and knowledge of business. Despite numerous studies on the diversity of leadership traits, certain criticisms have been levelled out on the trait leadership theory. Strategic leaders also facilitates a transformational atmosphere within an organization by embracing strategic leadership practices that regards to the leaders' confidence in the organizations' vision, personal responsibility, and sense of purpose, determination, persistence, and trust in employees and emphasis for accomplishments of goals rather than failures (Gill, 2011). Bekele and Darshan (2011) support this argument in that transformational leadership increases subordinates' job satisfaction which in turn increases organizational performance. Likewise, McGough (2010) avers that transformational leaders are responsible for shaping the organizations' future.

Table 4: Model Coefficients

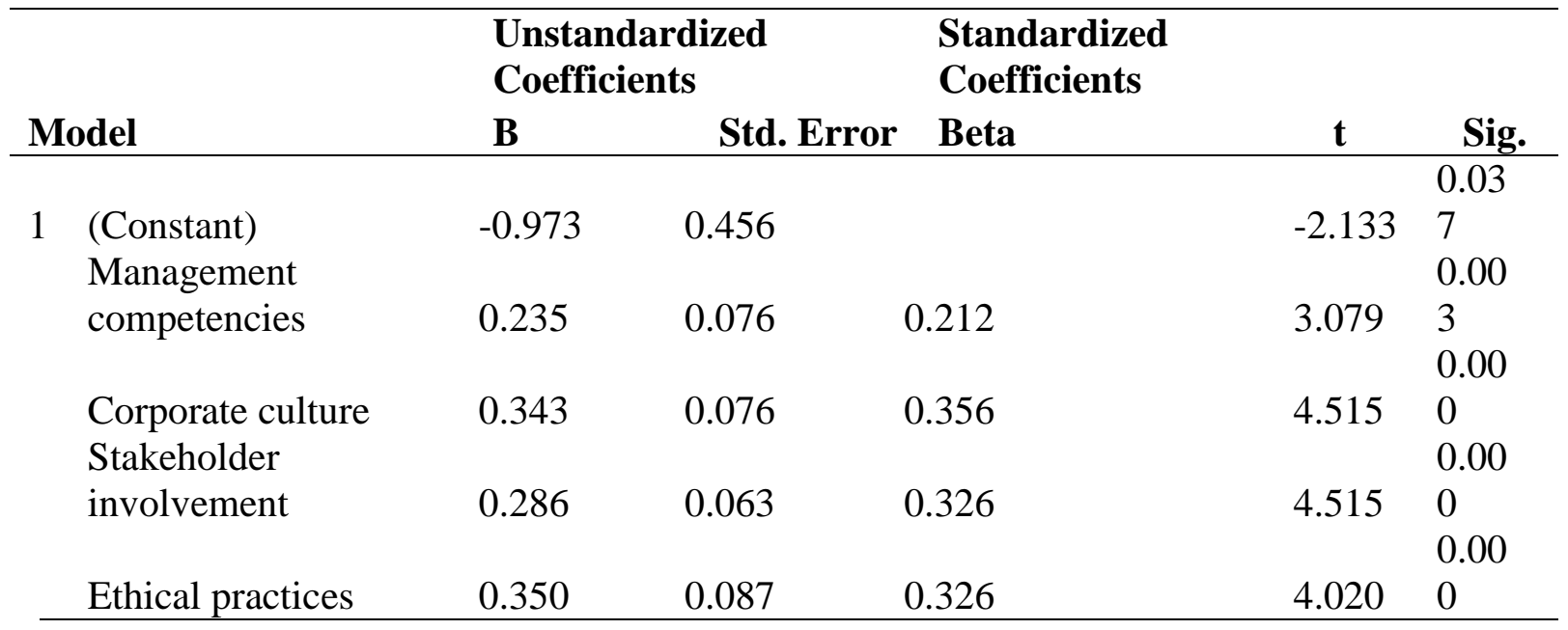

a Dependent Variable: Performance of the DCI

Table 4 generated the model coefficients as well as p-Value for each variable. The constant was found to be negative (-0.973) implying when management competencies, corporate culture, stakeholder involvement and ethical practices are all absent or held constant, performance of DCI will be negative and thus counterproductive. At the same time, when management competencies are positively increased by one unit, performance of DCI will increase by 0.235 units. This relationship is replicated when corporate culture, stakeholder involvement and ethical practices are each increased by one unit generating positive change on performance of DCI by $0.343,0.286$, and 0.350 respectively. This relationship can be summarized as $\mathrm{Y}=-0.973+0.235 \mathrm{X}_{1}+0.343 \mathrm{X}_{2}+0.286 \mathrm{X}_{3}+0.350 \mathrm{X}_{4}+\alpha$. Where $\mathrm{Y}$ is the dependent variable (Performance of the DCI in Nairobi City County, Kenya) while $\mathrm{X}_{1}=$ management competencies, $\mathrm{X}_{2}=$ corporate culture, $\mathrm{X}_{3}=$ stakeholder involvement, and $\mathrm{X}_{4}=$ ethical practices. $\alpha=$ an error term.

These findings generally support Transformational Leadership Theory which advocates for results oriented performance. In the context of this study, transformational leadership theory brings out the link between leadership flexibility and innovation in the sense of appropriate orientation in defining tasks and managing interrelationships in the organization. Transformational leadership provides important aspects of strategic leadership practices like concern for human capital. At the same time, transformational leaders always increase subordinates' motivation by clarifying the path towards which organizational performance is possible. Strategic leadership practice has been viewed as being able to contribute significantly and positively towards achieving organizational performance by motivating others to pursue the same strategic direction. This theory was relevant in this study for its 
focus on the role of the leader in motivating subordinates towards achieving an organization's goal (Bhatia, 2009).

\section{Conclusion}

Given the significance of significance of the variance ( $p$-Value < 0.05 ) and F-Value is 44.283 and further supported by R-Square $=0.76$, it can be concluded that management competencies, corporate culture, stakeholder involvement, and ethical practices are all essential strategic leadership aspect that require complete adoption if performance of an organization has to improve to the desired level. Of particular importance to achieve this performance include professional trainings, staff capacity building, possession of exemplary skills and ability, service without fear or favour, and believing in delivery of quality service. Other key aspects are diligent performance on the part of the staff, stakeholder participation in decision making process and community policing as well consulting with other arms of government. Over and above, it is important to have a practical code of conduct including core values, as well as having concrete ethical principles.

\section{Recommendations}

The researcher gives recommendations which are based on the findings from this study. First, to enhance management competencies, institutions should embrace adequate and effective professional trainings and capacity buildings. This should be accompanied by periodical competence assessment to identify and eventually evaluate skills and knowledge gap that exists with the institution. Secondly, the government through relevant policy making bodies should build up and enhance policies regulating leadership of government institutions. These policies should be designed to encourage strategic leadership and stakeholders' engagement in strategic management processes. Thirdly, government institutions should endeavor to embrace ethical practices and in particular cultivate on a practical code of conduct including core values, as well as having concrete ethical principles. Lastly, management should give direction to every part of the organization - from the corporate office to the loading dock at an institutional level. The management should have the ability to keep one eye on how the organization is currently adding value and the other eye on changes, both inside and outside the organization, that either threaten its position or present some new opportunity for adding value.

\section{REFERENCES}

Alshammari, A., Almutairi, N. N., \& Thuwaini, S. F. (2015). Ethical leadership: The effect on employees. International Journal of Business and Management, 10(3), 108.

Aosa, E. (1992). An empirical investigation of aspects of strategy formulation and implementation with large, private manufacturing companies in Kenya (Doctoral dissertation, University of Strathclyde).

Arnott, D. H. (1995). The five lenses of leadership. Journal of Leadership Studies, 2(1), 137141.

Awino, Z. B. (2001). Effectiveness and problems of strategy implementation of financing Higher Education in Kenya by the Higher Education Loans Board. Unpublished MBA Project, University of Nairobi.

Bakar, M. S., \& Mahmood, R. (2014). Linking transformational leadership and corporate entrepreneurship to performance in the public higher education institutions in Malaysia. Advances in Management and Applied Economics, 4(3), 109.

Becker, B. E., Huselid, M. A., Huselid, M. A., \& Ulrich, D. (2001). The HR scorecard: Linking people, strategy, and performance. Harvard Business Press. 
Bertocci, D. I. (2009). Leadership in organizations: There is a difference between leaders and managers. University Press of America.

Bettis, R. A., \& Hitt, M. A. (1995). The new competitive landscape. Strategic management journal, 16(S1), 7-19.

Bhatia, R. C. (2009). Business Organization and Management, (3rd Ed.). New Delhi: Ane Books Pvt. Ltd.

Boal, K. B., \& Hooijberg, R. (2000). Strategic leadership research: Moving on. The Leadership Quarterly, 11(4), 515-549.

Burns, J.M. (1978). Leadership. New York: Harper \& Row.

Chi, H. K., Lan, C. H., \& Dorjgotov, B. (2012). The moderating effect of transformational leadership on knowledge management and organizational effectiveness. Social Behavior and Personality: an international journal, 40(6), 1015-1023.

Chtalu, K. A. (2014). The Challenges related to police reforms in Kenya: a survey of Nairobi County, Kenya. Unpublished Master's Research Thesis). University of Nairobi, Kenya.

Daft, R. L., \& Marcic, D. (2016). Understanding management. Nelson Education.

Daft, R. L., \& Pirola-Merlo, A. (2009). The leadership experience (1st Asia Pacific ed.). South Melbourne, Australia: Cengage Learning.

Darshan, G. (2011). Effects of transformational leadership on subordinate job satisfaction in leather companies in Ethiopia. International Journal of Business Management and Economic Research, 2(5), 284-296.

Dawes, J., \& Rowley, J. (1998). Enhancing the customer experience: contributions from information technology. Management decision, 36(5), 350-357.

Dixon, M. L., \& Hart, L. K. (2010). The impact of path-goal leadership styles on work group effectiveness and turnover intention. Journal of Managerial Issues, 52-69.

Drucker Peter F. (1997): Critical Evaluations in Business and Management, Volume 1

Evans, M. G. (1970). The effects of supervisory behavior on the path-goal relationship. Organizational behavior and human performance, 5(3), 277-298.

Farkus, C. M. \& De Backer, P. (1996). Maximum Leadership: Five Strategies for Success from the World's Leading CEOs. London, UK:Perigee

Fitzgerald, L., Johnston, R., Brignall, T. J., Silvestro, R., \& Voss, C. (1991). Performance measurement in service industries. London: CIMA.

George, D., \& Mallery, P. (2003). SPSS for Windows step by step: A simple guide and reference 11.0 update ( $4^{\text {th }}$ ed.). Boston: Allyn \& Bacon

Gibson, J. L., Ivancevich, J.M \& dan James H.D. (2010). Organizational Behaviour Structure, Process. 9th. Edition, Irwin, Chicago.

Guillot, W. M. (2006). Strategic leadership: Defining the challenge. Air \& Space Power Journal, 17(4), 67.

Gupta, A. K., \& Govindarajan, V. (2000). Knowledge flows within multinational corporations. Strategic management journal, 21(4), 473-496.

Hair, J. F., Anderson, R. E., Tatham, R. L., \& Black, W. C. (2014). Multivariate Data Analysis, $5^{\text {th }}$ edition. New Jersey: Prentice-Hall International, Inc.

Hale, C. (2013) Hale Chair in applied Ethics copyright 2013

Hambrick, D. C. (1981). Specialization of environmental scanning activities among upper level executives. Journal of management studies, 18(3), 299-320.

Hamel, G., \& Prahalad, C. K. (2013). Creating global strategic capability. In Strategies in Global Competition (RLE International Business) (pp. 25-59). Routledge.

Hitt, M. A., \& Duane, R. (2006). R IRELAND a Robert E HOSKISSON. Strategic management: competitiveness \& globalization. 
House, R. J. (1971). A path goal theory of leader effectiveness. Administrative science quarterly, 321-339.

Kaplan, R. S. \& Norton, D. P. (1996). The balanced scorecard. Boston: Harvard Business School Press.

King'ori, J. K. (2013). An Investigation Of Factors Influencing Police Officers' Perception Of Police Reforms: A Case Of Kenya Police Service, Nairobi Area. Doctoral Dissertation. Nairobi University of Nairobi.

Kinuu, D., Maalu, J., \& Aosa, E. (2012). Factors influencing change management process at Tamoil Kenya Limited.

Kiraithe, E. R. I. C. (2011). Management of strategic change at the Kenya Police. Unpublished MBA Thesis, University of Nairobi.

Kirkpatick, S. A., \& Locke, E. A. (1986). Leadership: do traits matter?. Academy of Management Perspectives, 5(2), 48-60.

Kjelin, E. (2009). A concept analysis for strategic leadership. EBS Review, (26).

Koontz, H. \& Donnell, C. (1993). Introduction to Management. New York: McGraw-Hill Inc.

Laitinen, E. K. (2003). Financial rating of European technology companies: an international comparison. Journal of Business Finance \& Accounting, 29(7-8), 871-901.

Laverty, K. J. (1996). Economic "short-termism": The debate, the unresolved issues, and the implications for management practice and research. Academy of Management Review, 21(3), 825-860.

Lei, D., Hitt, M. A., \& Bettis, R. (1996). Dynamic core competences through meta-learning and strategic context. Journal of management, 22(4), 549-569.

Lewis, J., Packard, T., \& Lewis, M. (2007). Management of human service programs (4th ed.). Belmont, CA: Thompson/Brooks Cole

Lord, R. G., \& Shondrick, S. J. (2011). Leadership and knowledge: Symbolic, connectionist, and embodied perspectives. The Leadership Quarterly, 22(1), 207-222.

Lynch, Richard L.,Cross, Kelvin F.(1991) The Strategic Measurement And Reporting Technique (SMART) Pyramid

Mallery, P., \& George, D. (2003). SPSS for Windows step by step: a simple guide and reference. Allyn, Bacon, Boston,.

Mann, R. D. (1959). A review of the relationships between personality and performance in small groups. Psychological bulletin, 56(4), 241.

Maruca, R. F. (1994). The right way to go global: An interview with Whirlpool CEO David Whitwam. Harvard Business Review, 72, 134-134.

Mihelic, K. K., Msc, L.B. \& Tekavcic, M. (2010) Ethical Leadership. International Journal of Management and Information Systems

Mihelic, K.K., Msc, L.B. and Tekavcic, M. (2010) Ethical Leadership. International Journal of Management and Information Systems, 14, 31-41.

Mische, M. (2001). Strategic renewal: Becoming a high-performance organization (Vol. 23). Upper Saddle River, NJ: Prentice Hall.

Mugenda, O. M. and Mugenda, A.G. (2003) Research Methods, Quantitative and Qualitative Approaches. Nairobi: ACTS Press.

Mutemi, W. E. (2014). Challenges affecting the performance of police reservists in Kenya: the case of Loima Sub-County in Turkana County (Doctoral dissertation).

National Police Service Act No. 11a of 2011 Revised Edition 2016 [2015] Published By The National Council For Law Reporting With The Authority Of The Attorney-General

National Police Service Five Year Strategic Plan (2017-2022)

Ngugi, J. K., Ngugi, P. K., Were, M. S., \& Titany, L. (2012). The factors influencing service delivery in the national police service: a case of the Kenya police in Nairobi 
County. Journal of Research in International Business and Management, 2(11), 285-291.

Nguluu, J. (2006). Relationship between strategic management and performance of Tea manufacturing firms in Kenya. Unpublished MBA project Nairobi University.

Northouse, P. G. (2018). Leadership: Theory and practice. Sage publications.

Otley, D.T., (2008). Performance management: a framework for management control systems research. Management Accounting Research, 10.

Pearce, A. (2002). John (II), Robinson B. Richard, Jr.(1999/Strategic Management: Strategy.

Piccolo, R. F., Greenbaum, R., Hartog, D. N. D., \& Folger, R. (2010). The relationship between ethical leadership and core job characteristics. Journal of Organizational Behavior, 31(2-3), 259-278.

Piccolo, R. F., Greenbaum, R., Hartog, D. N. D., \& Folger, R. (2010). The relationship between ethical leadership and core job characteristics. Journal of Organizational Behavior, 31(2-3), 259-278.

Ransley, P. (2009). Report of the National task force on police reforms-revised abridged version December.

Rawat, S. R. (2015). Impact of transformational leadership over employee morale and motivation. Indian Journal of Science and Technology, 8, 25.

Richard, P. J., Devinney, T. M., Yip, G. S., \& Johnson, G. (2009). Measuring organizational performance: Towards methodological best practice. Journal of management, 35(3), 718-804.

Seyhan, O. (2014). A primer for transformational leadership in nonprofit sector. Yönetim Bilimleri Dergisi, 11(22), 253-275.

Sink, D. S. \& Tuttle, T.C. (1989). Planning and Measurement in Your Organization of the Future. Norcross, GA: IE Press.

Stogdill, R. M. (1948). Personal factors associated with leadership: A survey of the literature. The Journal of psychology, 25(1), 35-71.

Stogdill, R. M. (1948). Personal factors associated with leadership: A survey of the literature. The Journal of psychology, 25(1), 35-71.

Toor S. \& Ofori G. (2009) "Ethical Leadership: Examining the Relationships with Full Range Leadership Model, Employee Outcomes, and Organizational Culture. Journal of Business Ethics, 90, 533-547.

Van Weele, A. J. (2006). Purchasing \& Supply Chain Management: Analysis, Strategy, Planning and Practice (4th ed.). Australia: Thomson.

Veen-Dirks, P. \& Wijn, M. (2012). Strategic Control: Meshing Critical Success Factors with the Balanced Scorecard. Long Range Planning

Zaccaro, S. J. \& Klimoski, R. J. (2001) The Nature of Organization Leadership. JosseyBass, San Francisco.

This is an open-access article published and distributed under the terms and conditions of the $(\mathrm{cc}) \mathrm{EY}$ Creative Commons Attribution 4.0 International License of United States unless otherwise stated. Access, citation and distribution of this article is allowed with full recognition of the authors and the source.

Authors seeking to publish with an International Peer Reviewed Journal should consider https://www.ijcab.org/ by writing to the Editor at editor@ijcab.org. The articles must be quality and meet originality test. 